\title{
Aftimoon (Cuscuta reflexa Roxb.): A Parasitic Plant with Therapeutic Potentials
}

\section{Aaisha Ansari, Uzma Viquar* and Munawwar Husain Kazmi}

Department of Ilmul Advia, National Research Institute of Unani Medicine for

Skin Disorders, Hyderabad, Telangana, India

*Corresponding Author: Uzma Viquar, Reader, Department of Ilmul Advia, National Research Institute of Unani Medicine for Skin Disorders, Hyderabad, Telangana, India.
Received: September 28, 2020

Published: October 28, 2020

(C) All rights are reserved by Aaisha Ansari., et al.

\begin{abstract}
Aftimoon (Cuscuta reflexa Roxb.) is a parasitic plant used in the management of various skin disorders like vitiligo, pityriasis, mental disorder like depression, epilepsy, etc. and it is used as mufrad (single drug) in the form of powder, decoction, concoction etc and in the murakkab (compound formulations) form in the Unani system of medicine. The plant belongs to genus Cuscuta and family Cuscutaceae. This parasitic plant grows on different host plants in India upto thousands of feets and is found abundantly in the rainy season. It is yellowish in colour with thin swirly stem grows on other plants and trees as parasite commonly called as Dodder in English. Unani physicians have been using this plant since time immemorial to treat various illnesses pertaining to the disorder of humours in the body. A number of biologically active compounds like amarbelin, cuscutin, cuscutalin, etc have been isolated and important and significant pharmacological actions like anti-cancerous, anti-tumour, anti-inflammatory, antibacterial activities etc on aftimoon (Cuscuta reflexa Roxb) is reported in various studies. This paper aims to review and summarise knowledge presented in the classical Unani text and various scientific research being conducted on Cuscuta reflexa Roxb in order to generate a data based on evidences which will be helpful to the future research endeavours.
\end{abstract}

Keywords: Aftimoon; Cuscuta reflexa Roxb.; Parasitic Plant; Unani

\section{Introduction}

The healing substances for diseases are provided by nature itself. Even parasitic plants have been discovered and used as medicines since ancient times. Cuscuta reflexa Roxb. is one of the most commonly found parasitic plant in India. It is commonly distributed in India 's western Bengal plains. The different species of the Cuscuta genus are known to be widely distributed across the world where approximately 170 or more species have been known to occur. Although it is a plant parasite and is harmful and destroys the plant on which it is inhabitant, but it has great healing properties as a medicine. Cuscuta accumulates alkaloids and also other active metabolites from the plant that it hosts. It comprises various alkaloids, glycoside, flavonoids etc. It contains active compounds like amarbelin and kaempferol; stem has cuscutin, cuscutalin, bergenin, beta-sitosterol, luteolin and kaempferol [1]. It is a leafless parasitic climber with thin, slender and delicate stem bears flower, fruit and seeds. Cuscuta reflexa Roxb., is commonly called Aftimoon or Kasoos in the Unani System of medicine the seeds are known as
Tukhm-e Kasoos. In the Unani medicine system, the aerial parts of the plant are typically used in a dried form. Peculiarly fragrant, reddish and thin stemmed, aftimoon is considered to be of the highest quality $[2,3]$. It has been advised in a number of ailments by the renowned Unani physicians since ancient times. The Unani system of medicine successfully uses the plant in the diseases like Amraz i-Sawdāwi wa Balghamī (Diseases of black bile and phlegm), Amraz i-Dimaghi wa A'șābi (diseases of nervous system), Junoon (Mania), Sara (Epilepsy), Malikholia (melancholia) Amraze jild (skin diseases), other conditions like Deedan e Ama (Intestinal Worms), zofe kabid (liver debility), Ashobe Chashm (conjunctivitis), Tap i-kohna (chronic fever) Waram-ị kabid (Hepatitis), sartān (cancer), khafqān (Palpitaion), Tasannuj (spasm), nafakh (flatulence), aurām (inflammation) Wajaul-Mafāṣil (arthralgia) and it is specially mentioned useful for geriatric and debilitate people $[2-5,9]$. The plant is immensely used in the various traditional systems of medicine for the diseases like depression, melancholy, and other mental disorders, skin diseases, liver diseases and in the Ayurvedic system it is 
used in muscular pain, urination disorders, jaundice, fever, coughs etc. The entire plant is used for the treatment of most of the bilious disorders. It has no roots under the ground and develops as a fresh parasite on the host plant during the rainy season [6,7]. Alcoholic extract of the plant has been reported for hypotensive and bradycardia effects $[8,26]$. A number of bioactive molecules have been isolated and pharmacological activities have been reported till date. In the Unani classical texts Aftimoon is described to possess a number of pharmacological properties like Mushil-i- Sawdā' (purgative of black bile), Mushil-i-Balgham (purgative of Phlegmn), Mudir i bawl (Diuretic), Muhallil waram (Anti-inflammatory), etc which will be discussed below. In the present scenario there is a need for generating evidence based data and there is a great possibilities for working on the pharmacological attributions quoted and experienced by renowned Unani Physicians.

Fael khas (Main or prominent action): Dāfi'-ị Sawdā' (removes black bile) $[2,9]$.

\section{Scientific classification $[38,39]$}

\begin{tabular}{|l|c|}
\hline Kingdom & Plantae \\
\hline Subkingdom & Tracheobionta \\
\hline Super division & Spermatophyta \\
\hline Division & Magnoliophyta \\
\hline Class & Magnoliopsida \\
\hline Subclass & Asteridae \\
\hline Order & Solanales \\
\hline Family & Cuscutaceae (dodder family) \\
\hline Genus & Cuscuta L. \\
\hline Species & Cuscuta reflexa \\
\hline
\end{tabular}

Synonyms [5-7]

\begin{tabular}{|c|c|}
\hline English & Dodder \\
\hline Unani & Aftimoon \\
\hline Arabic & Kasus, Shajarus'sabagh, sharulzabiha \\
\hline Persian & Aftimoon, Tukhm-e-kasus \\
\hline Unani & Aftimoon, kasoos \\
\hline Hindi & Akashbela, Amarbela \\
\hline Sanskrit & Amarvela, akashavalli, Amaravallari, \\
\hline Punjabi & Nilathari \\
\hline Marathi & Kodiyagundal, Sadadari \\
\hline Telugu & Algusi \\
\hline Tamil & Akaswel, Amarabel \\
\hline Bengali & \\
\hline Gujrati & Koditana purgolalu \\
\hline
\end{tabular}

\section{Geographical distribution}

Various species of Cuscuta is distributed throughout the world. Found in tropical and subtropical regions of the world the species Cuscuta reflexa is prevalent throughout Indian Plains mainly in Bengal, in the regions of Himanchal Pradesh. It's also seen abundantly in Western Ghats and Ceylon. It is seen growing in the Himalayan regions upto thousands of feet [6,7]. It is also found in Thailand, Malaysia, Afghanistan and Nepal. It occurs most of the year, however flowering occurs around late October to March [10].

\section{Botanical description}

\section{Macroscopic}

Aftimoon (Cuscuta reflexa) is a perennial rootless, leafless, which shows an extensive climbing habit. It is a widespread creeper yearly parasitic plant. It grows as holoparasite and it has very low level of chlorophyll and photosynthetic activity, completely depends over the host plant for its survival. The plant is acrid and tastes bitter and sharp. The stems are long, narrowly twined, branched, glabrous, pale greenish-yellow, often dotted with red $[5,7,10]$. Flowers are single or in umbellate clusters of 2 - 4 in short racemes, pedicels is glabrous, short and generally curved; bracts is ovate to oblong, obtuse and fleshy and $1,5 \mathrm{~mm}$ long. Calyx is divided almost to the base, long, slightly irregular, $3 \mathrm{~mm}$ lobes, obtuse, glabrous and fleshy. Corolla is white; tube $6-8 \mathrm{~mm}$ by $4 \mathrm{~mm}$; lobes $2.5-3 \mathrm{~mm}$, almost cylindrical, acutely reflexed, almost at the base of corolla tube. Stamens lies in the throat of the corolla tube; filaments are scattered scarcely; anthers lies beyond the top of the corolla tube. Ovary is simple and ovoid with very short and thick style; two stigmas, which are distinct, thick, fleshy and large, 1.5 $\mathrm{mm}$ long. Capsules $68 \mathrm{~mm}$ wide, glabrous, circumscissile near the base, and depressed globose. Seeds are black and glabrous 2 - 4 in number $[7,10]$.

\section{Microscopic}

The stem T.S is round and wavy in outline. The outer boundary consists of a single layer of epidermis composed of various small cell shapes. Externally it is lined by a thin cuticle and there are several areas where stoma is present. The epidermis is accompanied by 3 - 4 layers of cells consisting of various sizes and shapes of thin walled parenchymatous cells. In some of the cells brown substance is seen. Endodermis is formed by tangentially elongated cells; a complete ring is often formed, but broken endodermis is seen in stem. The cells are filled with starch grains, prism-shaped granules and calcium oxalate crystals. The vascular bundles are simple, conjoint, collateral and in numbers of 15 - 20. Vascular bundles are arranged in a ring. The xylem lies on the outer side, it is surrounded by phloem in old stem. The phloem consists of parenchyma sieve 
tubes, accompanying cells, fibre and phloem parenchyma. The phloem within is very small. Also, few cells of cambium are found in some of the vascular bundles. The xylem is made up of vessels, parenchyma xylem and tracheids. Some schizogenous cells are seen at the junction of xylem and phloem, and in the cortex region. Unaligned parenchymatous forms the large pith [10].

Fruit: The pericarp of the fruit is thin and membranous, consists of an outer layer of tangential and narrowly oblong thin walled parenchymal cells. The parenchyma cells show a periclinal division at certain places: the inner layer consists of a large, barrel-shaped cell with very thick inner tangential and radial walls, the thickened part appears to be "U" shaped in the cross-section [5].

Seeds: Triangular to rectangular in TS; testa is thick and brittle; thick and echinate cuticle is seen present followed by a narrow region of epidermis which consists of radially elongated cells with thick walls: inner to epidermis lies a broad, compact, thin, radially elongated palisade like cell layer; mesophyll tissue is shrunk, collapsed, and forms a membranous zone. Attachment is seen to the Inner layer at some locations, but sometimes seen separated; embryo is minute and is embedded in the mass of shrunken cotyledons [5].

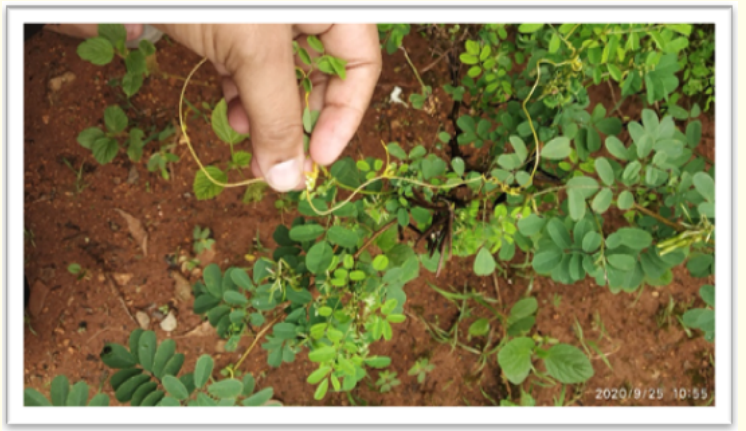

Figure 1: Cuscuta on Indigofera tinctoria plant.

Photo credit: Herbal garden; National Research Institute of Unani

Medicine for Skin Disorders, Hyderabad, India. Original photograph by author 1 .

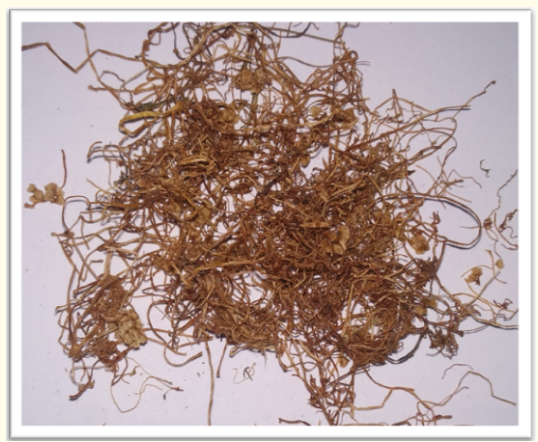

Figure 2: Aftimoon dried aerial parts of the plant. Photograph by author 1 .

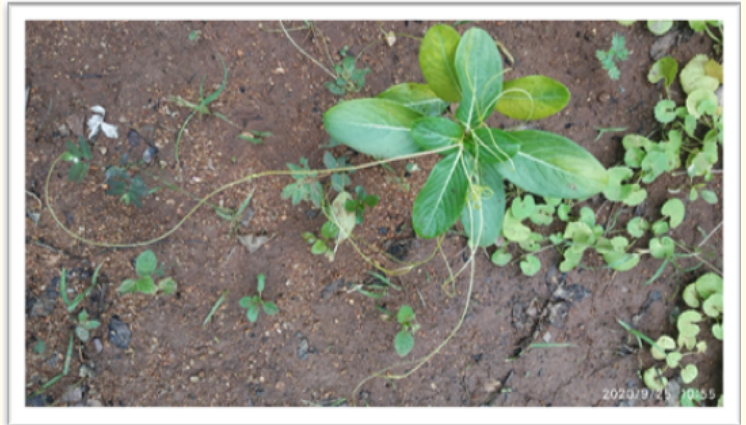

Figure 3: Cuscuta on Catharanthus roseus plant.

Photo credit: Herbal garden; National Research Institute of Unani Medicine for Skin Disorders, Hyderabad, India. Original photograph by author 1 .

\section{Part used (Ajza i mustamila)}

- Whole plant $[2-6,9]$.

- $\quad$ Stem and seeds [11].

\section{Temperament (Mizaj) [2-5,9]}

Hot and dry with a variation in the degree of hotness and dryness as described according to renowned Unani physicians.

\section{Dosage (Miqdar Khoraq) [2-5,9]}

Various Unani physicians have advised the drug in different doses where the dose ranges from $3 \mathrm{gm}$ to $21 \mathrm{gm}$.

\section{Toxicity (Muzir) [2-4]}

Harmful for people with condition of Mirra-i-Safrā' (serous bile). Also harmful for people of hot temperament as it may cause irritability, nausea and vomiting. It is also Muzir (harmful) for lungs. Aftimoon due to its basic temperament causes dryness of mouth, irritability and thirst. Therefore, correctives are adviced to be used long with the intake of drug.

Correctives (Musleh) [2-4]

- $\quad$ Kateera (Tragacanth gum)

- Zafran (Crocus sativus)

- Roghan badam (Almond oil)

- Kasni (Cichorium intybus) [4,9].

Substitute (Badal)

- Ustukhuddus (Lavendula Stoechhus) [3]

- Basfaij (Polypodium vulgare) [3]

- Hasha (Thymus vulgaris) [2,3]

- $\quad$ Turbud (Ipmoea turpethum) $[2,10]$

- Afsanteen (Artemisia absinthium) [4,9]. 
Compound formulations $[5,10,12]$

Sharbat Deenar, Itrifal Aftimoon, Sikanjbeen Aftimooni, Ma'jūn Najaah, Majūin Chobchini, Arq e Musaffi.

\section{Pharmacological actions and therapeutic uses}

It is a good purgative for Balgham (phlegm), Sawdā' (black Bile) and Safrā (yellow bile) and is useful in different ailments arising due to derangement of these humours specially sawda and balgham as mentioned in the classical Unani texts it is found useful in treat Malikholia (Melancholia), Sara (Epilepsy), Kaboos (Nightmare), Falij (Paralysis), Laqwa (Facial paralysis), Khadar (Numbness), Waswas (Anxiety), Mania, Junoon (Schizophrenia), Deedan e $a m^{\prime} a$ (Intestinal worm infestation) and various skin diseases owing to its property of being mushil i Sawdā' (Purgative of Bile), mushily i ballgham (Purgative of Phlegm), musaffi dam (Blood Purifier), mufatteh sudad (deobstruent). Mulattif (Demulcent) Muqawwi (Tonic), Mulattif (demulcent), Muhallil (resolvent) [2,3,4,5,9,10]. It is reported to be used as blood purifier, emmenagogue, diuretic, aphrodisiac, expectorant, carminative, antihelmintic, sedative and the muscular and joint pain [7]. plant as a whole possesses antihelmintic purgative and alterative properties stem is useful in bilious and liver disorders. Externally useful in itching and seeds are carminative and anodyne [6].

\section{Phytochemical constituents}

Phytochemical examinations have shown the presence of therapeutic compounds such as flavonoids, alkaloids, lignans, saponins, phenolics, tannins, resin and glycosides. Dulcitol, Luteolin, Quercetin A glycoside or luteolin [5]. Organic: Alkaloid, protein, flavonoids, resin, tannin, glycosides and carbohydrates. Inorganic: Aluminium, iron, calcium, sodium and potassium [10]. The seeds contain amarbelin and kaempferol like alkaloids. Stem has cuscutin, cuscutatin, luteolin, beta-sitosterol, bergenin and kaempferol [1]. A study for extracting the bioactive constituents from the different fractions of stems of Cuscuta reflexa Roxb. using GC-MS revealed two known and 12 unknown compounds [35]. Two tetrahydrofuran derivatives, Swarnalin and cis-swarnalin have been isolated in a study also reported for its free radical scavenging activity [16].

\section{Therapeutic activities in Cuscuta reflexa Roxb}

Experimental studies have shown that Cuscuta species have a wide range of biological activities, notably, anticancer, anti-inflammatory, immunomodulatory, antioxidants, antidiabetes, antiviral and anxiolytic etc.

\begin{tabular}{|c|c|c|}
\hline Therapeutic activities & Extract used & Observation and Findings \\
\hline Antioxidant activity & Alcoholic extract & $\begin{array}{l}\text { A study on Cuscuta reflexa and Cassytha filiformis revealed that both possess an- } \\
\text { tioxidant activity, in which Cuscuta reflexa is found more effective in scavenging } \\
\text { free radicals and superoxide radical than the Cassytha filiformis [13]. }\end{array}$ \\
\hline Anti-HIV activity & Crude water extract & $\begin{array}{l}\text { Cuscuta reflexa water extract exhibited anti HIV activity which could be due to } \\
\text { combinatory effects with compounds of different modes of action [14]. }\end{array}$ \\
\hline Antibacterial activity & Methanolic extract & $\begin{array}{l}\text { The methanol extract of Cuscuta reflexa exhibited anti-bacterial and free radicals } \\
\text { scavenging activity }[15,16] \text {. }\end{array}$ \\
\hline Anti-cancerous activity & Water extract & $\begin{array}{l}\text { Anti-cancer activity was analysed on Hep3B cells by MTT assay, DAPI staining, } \\
\text { annexin V staining and SQ-RT PCR analysis of BAX, Bcl-2, p53 and survivin. The } \\
\text { extract induced apoptosis in Hep3B cells through the up regulation of p53, BAX } \\
\text { and down regulation of Bcl-2 and surviving [17]. }\end{array}$ \\
\hline Anti-tumor activity & $\begin{array}{l}\text { Ethanol extract } \\
\text { Chloroform extract }\end{array}$ & $\begin{array}{l}\text { The results of the study revealed that chloroform and ethanolic extract of } \mathrm{Cus} \text { - } \\
\text { cuta reflexa exhibit significant antitumor activity in mice comparable to standard } \\
\text { used, } 5 \text {-fluorouracil [18]. }\end{array}$ \\
\hline Anti-convulsant activity & Methanolic extract & $\begin{array}{l}\text { The study showed that the methanol extract of Cuscuta reflexa significantly in- } \\
\text { creased catecholamine levels in the brain mice after } 6 \text { weeks of dose-dependent } \\
\text { therapy. The extract also substantially raised the levels of GABA, glutamine and } \\
\text { glutamate relative to the control groups. It reveals that Cuscuta reflexa extract } \\
\text { possesses anticonvulsant activity [19]. }\end{array}$ \\
\hline Hypoglycemic activity & Methanolic extract & $\begin{array}{l}\text { Cuscuta reflexa Roxb. methanolic extract and its subsequent ethyl acetate fraction } \\
\text { shows significant inhibition against } \alpha \text {-Glucosidase enzyme. Inhibition of this } \\
\text { enzyme prolongs the absorption time of glucose in the blood after a meal [20]. }\end{array}$ \\
\hline Diuretic activity & $\begin{array}{l}\text { Aqueous extract } \\
\text { Alcoholic extract }\end{array}$ & $\begin{array}{l}\text { Both the extracts of Cuscuta reflexa is reported to show diuretic activity in wistar } \\
\qquad \text { rat [21]. }\end{array}$ \\
\hline
\end{tabular}




\begin{tabular}{|c|c|c|}
\hline Antipyretic activity & $\begin{array}{l}\text { Aqueous extract } \\
\text { Ethanolic extract }\end{array}$ & $\begin{array}{l}\text { A study is reported in which at the dose of } 400 \mathrm{mg} / \mathrm{kg} \text { body weight the aqueous } \\
\text { and ethanol extract reduced } 79 \% \text { and } 83.8 \% \text { respectively of the elevated rectal } \\
\text { temperature in rat as compared to reference drug paracetamol ( } 96.5 \%) \text { after } 6 \mathrm{~h} \\
\text { of treatment. The ethanol extract was found to be slightly potent than the aque- } \\
\text { ous extract [22]. }\end{array}$ \\
\hline Hepatoprotective activity & Methanolic extract & $\begin{array}{l}\text { The study with methanol extract of Cuscuta reflexa reduced the alkaline phos- } \\
\text { phatase as well as the total bilirubin levels, indicating its protective effect of liver } \\
\text { and improvement of its function [23]. }\end{array}$ \\
\hline Anxiolytic activity & Methanolic extract & $\begin{array}{l}\text { The study reports methanol extract of Cuscuta reflexa showed significant } \\
\text { anxiolytic effect at doses } 400 \mathrm{mg} / \mathrm{kg} \text { and } 200 \mathrm{mg} / \mathrm{kg} \text { and could serve as a good } \\
\text { anxiolytic agents and seems to be promising for the development of phytomedi- } \\
\text { cines for anxiety [24]. }\end{array}$ \\
\hline Anti-inflammatory activity & Aqueous extract & $\begin{array}{l}\text { A study is reported in which the water extract of Cuscuta reflexa was analysed in } \\
\text { vitro The study showed that Cuscuta reflexa inhibits lipopolysaccharide induced } \\
\text { inflammatory responses in murine macrophage cell line (RAW264.7) through } \\
\text { interplay of TNF- } \alpha \text {, COX-2 and NF- } \mathrm{KB} \text { signalling [17]. }\end{array}$ \\
\hline Antihelminthic Activity & $\begin{array}{l}\text { Chloroform extract } \\
\text { Methanol extract }\end{array}$ & $\begin{array}{l}\text { A study is reported in which Crude extracts of Cuscuta reflexa shows a dose de- } \\
\text { pendant inhibition of spontaneous motility (Paralysis) of earthworms (Pheretima } \\
\text { posthuma) in-vitro. The petroleum ether, chloroform and methanol extracts have } \\
\text { shown anthelmintic activity, which was compared with albendazole as reference } \\
\text { drug. The exact mode of action and the constituents responsible for the anthel- } \\
\text { mintic activity needs to be investigated [25]. }\end{array}$ \\
\hline
\end{tabular}

Original contributions with reference to studies on Cuscuta reflexa Roxb

\begin{tabular}{|c|c|c|c|}
\hline Year & Study title & Result & Reference \\
\hline 1992 & $\begin{array}{l}\text { "Pharmacological Actions of } \\
\text { Cuscuta reflexa." }\end{array}$ & $\begin{array}{l}\text { The study shows that the ethanol extract of Cuscuta reflexa causes a dose- } \\
\text { dependent decreases in arterial blood pressure and heart rate in pentothal } \\
\text { anesthetized rats. The Study also reports that the hypotensive and bradycar- } \\
\text { diac effects of } C \text {. reflexa are independent of cholinergic receptor stimulation } \\
\text { or adrenergic receptor blockade. In spontaneously beating guinea-pig atria, } \\
\text { C. reflexa it caused decreases in the force and rate of atrial contractions. In } \\
\text { guinea-pig ileum, } C \text {. reflexa inhibited both acetylcholine- and histamine- } \\
\text { induced contractions to a similar extent. } C \text {. reflexa also abolished spontaneous } \\
\text { contractions of rat uterus. These data indicate that } C \text {. reflexa in a non-specific } \\
\text { depressant on all the isolated tissues tested and this action is probably re- } \\
\text { sponsible for its hypotensive and bradycardiac effects observed in vivo. }\end{array}$ & [26] \\
\hline 2003 & $\begin{array}{l}\text { "Evaluation of psychopharma- } \\
\text { cological effects of petroleum } \\
\text { ether extract of Cuscuta reflexa } \\
\quad \text { Roxb stem in mice". }\end{array}$ & $\begin{array}{l}\text { The study reports that the extract treated mice show prolonged sleeping time, } \\
\text { Sedation, decreased motor activity and has a CNS depressant effect. }\end{array}$ & [27] \\
\hline 2003 & $\begin{array}{l}\text { "Onset of puberty and ovar- } \\
\text { ian steroidogenesis following } \\
\text { administration of methanolic } \\
\text { extract of Cuscuta reflexa Roxb. } \\
\text { stem and Corchorus olitorius } \\
\text { Linn. seed in mice." }\end{array}$ & $\begin{array}{l}\text { The study reports that the methanolic extract of Cuscuta reflexa stem and } \\
\text { Corchorus olitorius seed on the onset of reproductive causes a remarkable } \\
\text { delay in sexual maturation as evidenced by the age at vaginal opening and } \\
\text { appearance of first estrus (cornified smear) in extract treated mice as studied } \\
\text { by means of biochemical techniques. }\end{array}$ & [28] \\
\hline 2005 & $\begin{array}{l}\text { "Hepatoprotective activity } \\
\text { of Cuscuta reflexa extract on } \\
\text { experimental liver damage in } \\
\text { rats." }\end{array}$ & $\begin{array}{l}\text { The study reveals that the ethanol extract of buds of Cuscuta reflexa, caused } \\
\text { significant decreases in the CCl4-induced elevated levels of, SGPT and ALP, } \\
\text { indicating that it possess significant hepatoprotective activity against CCl4- } \\
\text { induced liver toxicity in rats . }\end{array}$ & [29] \\
\hline
\end{tabular}




\begin{tabular}{|c|c|c|c|}
\hline 2008 & $\begin{array}{l}\text { "Effect of Cuscuta reflexa Roxb } \\
\text { on androgen-induced alopecia." }\end{array}$ & $\begin{array}{l}\text { The study demonstrates that the petroleum ether extract of Cuscuta reflexa } \\
\text { and its isolate is useful in treatment of androgen-induced alopecia by inhibit- } \\
\text { ing the enzyme } 5 \alpha \text {-reductase. }\end{array}$ & [30] \\
\hline 2010 & $\begin{array}{l}\text { "Effect of cuscuta reflexa stem } \\
\text { and calotropis procera leaf } \\
\text { extracts on glucose tolerance in } \\
\text { glucose-induced hyperglycemic } \\
\text { rats and mice." }\end{array}$ & $\begin{array}{l}\text { In the study the hypoglycemic effects of chloroform and methanol extracts of } \\
\text { whole plants of Cuscuta reflexa, and methanol extract of leaves of Calotropis } \\
\text { procera were investigated in oral glucose tolerance tests in Long Evans rats } \\
\text { and Swiss albino mice, respectively. Both methanol and chloroform extracts of } \\
\text { Cuscuta reflexa whole plant demonstrated significant oral hypoglycemic activ- } \\
\text { ity in glucose-loaded rats in a dose dependent manner. }\end{array}$ & [31] \\
\hline 2012 & $\begin{array}{c}\text { "Ethonomedicinal, Antibacte- } \\
\text { rial and Antifungal Potential- } \\
\text { ity of Centella asiatica,Nerium } \\
\text { indicum and Cuscuta reflexa } \\
\text { - Widely Used In Tiwa Tribe } \\
\text { of Morigaon district of Assam, } \\
\text { India". }\end{array}$ & $\begin{array}{l}\text { In the study Cuscuta reflexa was found beneficiall against the growth of } \\
\text { Staphylococcus aureus. }\end{array}$ & [32] \\
\hline 2014 & $\begin{array}{l}\text { "A study on the extracts of Cus- } \\
\text { cuta reflexa Roxb. in treatment } \\
\text { of cyclophosphamide induced } \\
\text { alopecia". }\end{array}$ & $\begin{array}{l}\text { The study with petroleum ether and ethanolic extract of Cuscuta reflexa at the } \\
\text { dose } 250 \mathrm{mg} / \mathrm{kg} \text { in male swiss albino rats (Cyclophosphamide induced alo- } \\
\text { pecia) shows hair regrowth. Histopathology and gross morphologic observa- } \\
\text { tions revealed active follicular proliferation. }\end{array}$ & [33] \\
\hline 2014 & $\begin{array}{l}\text { "Phytochemical investigation } \\
\text { and } \\
\text { evaluation of } \\
\text { antimutagenic activity of the } \\
\text { extract of } \\
\text { Cuscuta reflexa Roxb. by Ames } \\
\text { Test" }\end{array}$ & $\begin{array}{l}\text { The study reports that the phytochemical investigation of methanol extract } \\
\text { of C. reflexa Roxb. yielded three flavonoids Isorhamnetin, Isorhamnetin-3-0- } \\
\text { glucoside and Isorhamnetin3-0-robinobioside. The extract was reported } \\
\text { to exhibit significant antimutagenic potential by Ames test against known } \\
\text { positive mutagens 2-aminofluorine, 4-nitro-o-phenylenediamine and sodium } \\
\text { azide against Salmonella typhimurium TA } 98 \text { and TA } 100 \text { bacterial strains. }\end{array}$ & [34] \\
\hline 2018 & $\begin{array}{l}\text { "Identification of bioactive } \\
\text { constituents from different frac- } \\
\text { tions of stems of Cuscuta reflexa } \\
\text { Roxb. using GC-MS." }\end{array}$ & $\begin{array}{l}\text { The study revealed two known compounds i.e. 2-Methoxy-4-vinyl phenol } \\
\text { \& Benzofuran-2,3-dihydro also } 12 \text { unknown compounds that are 3,5-di- } \\
\text { tert-Butyl-4-hydroxyanisole; Hexatriacontane; n-Hexadecanoic acid; Scop- } \\
\text { arone; Hexadecanoic acid methyl ester; 1,3-Benzenediamine, N, N, N', N' } \\
\text { tetramethyl; Phenol, } 4 \text { (3-hydroxy1propenyl), 2-methoxy; Phenol, 2,4 bis } \\
\text { (1,1dimethylethyl); 2,3,5,6-Tetramethyl para phenylene diamine; Retinoic } \\
\text { acid-5,6-epoxy-5,6-dihydro; 2,4-Dihydroxy-2,5-dimethyl-3 (2H)furan-3-one; } \\
\text { 2,3-dihydro-3,5-dihydroxy-6-methyl-2-Propyl-tetrahydro-pyran-3-ol; Pregn- } \\
\text { 4-ene-18-oic acid as some of the major compounds in its different fractions. }\end{array}$ & [35] \\
\hline 2019 & $\begin{array}{l}\text { "Effect of ethanolic extract of } \\
\text { Cuscuta reflexa on high fat diet- } \\
\text { induced obesity in Wistar rats". }\end{array}$ & $\begin{array}{l}\text { The study shows that treatment with ethanolic extract of Cuscuta reflexa } \\
\text { produced significant dose dependent decrease in the body weight, BMI, Lee's } \\
\text { index, feed intake (in Kcal). Also caused reduction in the levels of serum TC, } \\
\text { TG, LDL, VLDL and glucose and the level of HDL was enhanced as compared to } \\
\text { HFD fed group. The results suggest that administration of Cuscuta reflexa can } \\
\text { inhibit the development of obesity in HFD-induced obesity. }\end{array}$ & [36] \\
\hline 2020 & $\begin{array}{l}\text { "Effect of Cuscuta reflexa extract } \\
\text { on Experimentally Induced } \\
\text { Hypertension in normal and } \\
\text { Streptozotocin Induced Diabe- } \\
\text { tes in Rats". }\end{array}$ & $\begin{array}{l}\text { The study shows Cuscuta reflexa possess significant antidiabetic activity and } \\
\text { antihypertensive activity in experimentally induced hypertension in normal } \\
\text { and streptozotocin induced diabetic rats. }\end{array}$ & [37] \\
\hline
\end{tabular}




\section{Materials and Methods}

Review of literature was done referring to classical Unani literature and scholarly articles and an account of published original work done.

\section{Discussion}

This article reviewed the literature about Aftimoon in detail for its pharmacological characteristics and traditional uses thereby illustrating, focusing and enhancing the knowledge about its efficacy and effectiveness. Traditional medicines, like the Unani medicine system, have been using this plant as medicine in the form of single and compound formulation since ancient times, based on well-established literature and its use on the basis of experience by various Unani renowned scholars suggesting its effectiveness; however, clinical evidence and Published data in the field of Unani medicine has yet to be achieved in terms of evidence based scientific studies.

\section{Conclusion}

The various pharmacological activities of Cuscuta reflexa have been extensively reviewed in the article as apparent through the studies mentioned above. Cuscuta reflexa is a quite promising drug though it is a plant parasite but can be promoted for being use as alternative source of medicine in various ailments. In the Unani classical texts a vast details on uses and pharmacological activities have been mentioned yet there is a need for generating evidence by performing trials and yet providing the ailing masses with a great deal of healing through natural sources generating and firming up the research in the field of Unani system of medicine.

\section{Financial Interest}

No financial interest.

\section{Conflict of Interest}

No conflict of interest.

\section{Bibliography}

1. Khare CP. "Indian Medicinal Plants: An illustrated dictionary". New Delhi: Springer Verlag Berlin/Heidelberg, Springer science business media LLC (2007): 189.

2. Baitar Ibn and Al Jamiul. "Mufradat ul advia wal aghziya (Urdu translation, Part I)”. New Delhi: CCRUM; YNM: 54-56.

3. Ghani M and Khazainul Advia. Part III. Lahore: Sheikh Muhammad Basheer and Sons; YNM: 1039-1047.

4. Azam HM and Muheet-e-Azam. "Central Council for Research in Unani Medicine, part 1 (2002): 263.
5. Anonymous. "The Unani Pharmacoepia, Part I, Volume III". New Delhi: CCRUM, Dept. of AYUSH, Ministry of H and FW, Govt. of India (2007): 1-2.

6. Nadkarni K. "The Indian Materia”. Medica Bombay: A.K Nadkarni Publishers 1 (1936): 482-483.

7. Kirtikar KR and Basu BD. "Indian Medicinal Plants, $3^{\text {rd }}$ edition". Sri Satguru Publications, Delhi 8 (2001): 2401-2403.

8. William C Evans. "Trease and Evans Pharmacognosy". Saunders Elsevier's Publications, $16^{\text {th }}$ edition (2009): 37.

9. Kabeeruddin H. "Makhzan-ul-Mufradat Al-Maroof Khawas-ulAdvia”. Aijaz Publishing House, New Delhi, India (2000): 7983.

10. Anonymous. "Standardisation of single drugs of unani medicine, Part II". New Delhi: CCRUM, Ministry of H and FW, Govt. of India 7.8 (1992): 10-12.

11. Anonymous. "The Wealth of India-Raw Materials. New Delhi: National Institute of Science Communication and Information Resources, CSIR 10 (2003): 171-177.

12. Anonymous. "Qarabadeen Sarkari”. New Delhi: CCRUM, Ministry of H and FW, Govt. of Indi (2006): 7.

13. Sharma S., et al. "Comparative antioxidant activity of Cuscuta reflexa and Cassytha filiformis". Journal of Pharmacy Research 5.1 (2012): 441-443.

14. Mahmood N., et al. "Constituents of Cuscuto reflexa are anti-HIV Agents". Antiviral Chemistry and Chemotherapy 8.1 (1997): 70-74.

15. Pal DK., et al. "Antibacterial activity of Cuscuta reflexa stem and Corchorus olitorius seed". Fitoterapia 77.7-8 (2006): 589-591.

16. Uddin Shaikh J., et al. "Swarnalin and cis-swarnalin, two new tetrahydrofuran derivatives with free radical scavenging activity, from the aerial parts of Cuscuta reflexa". Natural Product Research 21.7 (2007): 663-668.

17. Suresh V., et al. "In vitro anti-inflammatory and anti-cancer activities of Cuscuta reflexa Roxb". Journal of Ethnopharmacology 134.3 (2011): 872-877.

18. Chatterjee Dandopani., et al. "Evaluation of antitumor activity of Cuscuta Reflexa Roxb (Cuscutaceae) against Ehrlich ascites carcinoma in Swiss albino mice". Tropical Journal of Pharmaceutical Research 10.4 (2011): 447-454.

19. Gupta M., et al. "Studies on brain biogenic amines in methanolic extract of Cuscuta reflexa Roxb. and Corchorus olitorius Linn. seed treated mice". Acta Poloniae Pharmaceutica 60.3(2003): 207-210. 
20. Anis Erum., et al. " $\alpha$-glucosidase inhibitory constituents from Cuscuta reflexa". Chemical and Pharmaceutical Bulletin 50.1 (2002): 112-114.

21. Sharma Sakshy., et al. "Comparative study of Cuscuta reflexa and Cassytha filiformis for diuretic activity". Pharmacognosy Research 1.5 (2009): 327.

22. Bhattacharya Sanjib and Bodhisattva Roy. "Preliminary investigation on antipyretic activity of Cuscuta reflexa in rats". Journal of Advanced Pharmaceutical Technology and Research 1.1 (2010): 83.

23. Balakrishnan BR., et al. "Effect of methanol extract of Cuscuta reflexa aerial parts on hepatotoxicity induced by antitubercular drugs in rats". International Journal of Applied Research in Natural Products 3.1 (2010): 18-22.

24. Thomas Sujith., et al. "Evaluation of anxiolytic effect of whole plant of Cuscuta reflexa". World Journal of Pharmaceutical Sciences 4 (2015): 1245-1253.

25. Udavant Pavan Bhausaheb., et al. "In vitro anthelmintic activity of stems of Cuscuta reflexa". International Journal of Bioassays (IJB) (2012).

26. Gilani Anwar-Ul Hassan and Khalid Aftab. "Pharmacological actions of Cuscuta reflexa". International Journal of Pharmacognosy 30.4 (1992): 296-302.

27. Pal D., et al. "Evaluation of phychopharmacological effects of petroleum ether extract of Cuscuta reflexa Roxb. stem in mice". Acta Poloniae Pharmaceutica - Drug Research 60.6 (2003): 481-486.

28. Gupta M., et al. "Onset of puberty and ovarian steroidogenesis following adminstration of methanolic extract of Cuscuta reflexa Roxb. stem and Corchorus olitorius Linn. seed in mice". Journal of Ethnopharmacology 89.1 (2003): 55-59.

29. Pradhan D., et al. "Hepatoprotective activity of Cuscuta reflexa extract on experimental liver damage in rats". Hamdard Medicus 48.1 (2005): 129-131.

30. Pandit Shweta., et al. "Effect of Cuscuta reflexa Roxb on androgen-induced alopecia". Journal of Cosmetic Dermatology 7.3 (2008): 199-204.

31. Rahmatullah Mohammed., et al. "Effect of Cuscuta reflexa stem and Calotropis procera leaf extracts on glucose tolerance in glucose-induced hyperglycemic rats and mice". African Journal of Traditional, Complementary and Alternative Medicines 7.2 (2010): 109-112.
32. Kalita Debajit and Jagat Saikia. "Ethonomedicinal, antibacterial and antifungal potentiality of Centella asiatica, Nerium indicum and Cuscuta reflexa-widely used in Tiwa Tribe of Morigaon district of Assam, India". International Journal of Phytomedicine 4 (2012): 380-385.

33. Patel Satish., et al. "A study on the extracts of Cuscuta reflexa Roxb. in treatment of cyclophosphamide induced alopecia". DARU Journal of Pharmaceutical Sciences 22.1 (2014): 7.

34. Dokuparthi Sudheer Kumar., et al. "Phytochemical investigation and evaluation of antimutagenic activity of the extract of Cuscuta reflexa Roxb by Ames Test". International Journal of Pharmaceutical Sciences and Research 5.8 (2014): 3430.

35. Rath Diptirani., et al. "Identification of bioactive constituents from different fractions of stems of Cuscuta reflexa Roxb. using GC-MS". Natural Product Research 32.16 (2018): 1977-1981.

36. Kaur Amanpreet., et al. "Effect of ethanolic extract of Cuscuta reflexa on high fat diet-induced obesity in Wistar rats". Obesity Medicine 14 (2019): 100082

37. Jadhav GB., et al. "Effect of Cuscuta reflexa extract on Experimentally Induced Hypertension in normal and Streptozotocin Induced Diabetes in Rats". Research Journal of Pharmacy and Technology 13.3 (2020): 1351-1355.

38. Cuscuta reflexa (dodder). CABI (2020).

39. USDA PLANTS Cuscuta reflexa Roxb (2020).

\section{Assets from publication with us}

- Prompt Acknowledgement after receiving the article

- Thorough Double blinded peer review

- Rapid Publication

- Issue of Publication Certificate

- High visibility of your Published work

Website: www.actascientific.com/

Submit Article: www.actascientific.com/submission.php Email us: editor@actascientific.com

Contact us: +919182824667 